\title{
Alquran dan Toleransi di Indonesia: Sebuah Analisa Surat al-Bāqarah: 148
}

Muhammad Alan Juhri

Fakultas Ushuluddin UIN Sunan Kalijaga Yogyakarta

alanjuhri25@gmail.com

\begin{abstract}
This paper discusses tolerance based on Surah al-Bāqarah verse 148. By using the method of library study, the researcherdiscusses different views on tolerance from religious perspectives, especially based on Surah al-Bāqarah verse 148. This study finds information that this first has been used to emphasize two things: first, the importance of respecting diversity as an objective fact, secondly the importance of striving seriously in terms of goodness as an important element in a pluralistic society.
\end{abstract}

Keywords: Plurality Religion, Fastabiq al-Khairāt, Contextual, QS. al-Bāqarah: 148

\begin{abstract}
Abstrak: Makalah ini membahas Toleransi berdasarkan surat al-Bāqarah ayat 148. Dengan menggunakna metode studi kepustakaan, peneliti menjawab pandangan tentang toleransi dalam perspektif agama, khususnya berdasarkan surat al-Bāqarah ayat 148. Kajian ini menemukan informasi bahwa dalam surat AlBāqarah ayat 148 dapat digunakan untuk menekankan dua hal: pertama, pentingnya menghargai keragaman sebagai fakta objektif, kedua pentingnya berusaha dengan sungguh-sungguh dalam hal kebaikan sebagai elemen penting dalam bermasyarakat yang plural.
\end{abstract}

Keywords: Pluralitas Agama, Fastabiq al-Khairāt, Kontekstual,

QS. Al-Bāqarah: 148.

\section{Pendahuluan}

Pluralitas merupakan suatu keniscayaan yang selalu mengiringi kehidupan manusia dan tidak akan dapat dihindari sampai kapanpun. Allah telah menciptakan manusia dalam pluralitas dan menjadikannya bagian dari kepluralan tersebut. Artinya, Allahlah yang menghendaki makhluknya berada dalam 
keberagaman. Bukan hanya dalam hal fisik saja, melainkan juga berbeda dalam hal ide, gagasan, keyakinan, dan beragama. Hal ini sejalan dengan beberapa firman-Nya dalam Alquran:

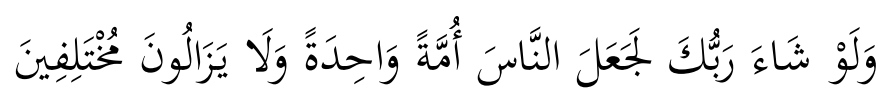

Andai Tuhanmu menghendaki, tentu Dia menjadikan manusia umat yang satu. Dan tetapi mereka senantiasa berbeda. (QS. Hūd: 118)

Redaksi seperti di atas cukup banyak diulang dalam Alquran, di antaranya QS. al-Mā'idah: 48 dan QS. Yunūs: 99 di mana Allah sangat menghendaki manusia diciptakan berbeda-beda. Sehingga ini menunjukkan sangat logis bahwa Allah juga memberikan perlindungan kepada para pemeluk agama yang berbedabeda tersebut. ${ }^{1}$ Di sisi lain, Allah juga menyatakan bahwa tujuan diciptakannya manusia dalam keberagaman tersebut ialah supaya mereka saling kenal mengenal (QS. al-Ḥujurāt: 13).

Di sisi lain, disebabkan karena pemahaman yang dangkal, fenomena pluralitas ini sangat sulit diterima oleh beberapa kalangan, khususnya Indonesia. Bahkan beberapa tahun yang lalu, Majelis Ulama Indonesia (MUI) sempat mengeluarkan fatwa agama yang mengharamkan gagasan pluralisme. Karena dianggap sebagai sesuatu yang menyesatkan dan dapat mengikis keyakinan umat beragama. $^{2}$ Tak heran jika akhir-akhir ini begitu marak terjadi konflik lantaran perbedaan pemahaman keagamaan yang dijadikan alasan untuk melakukan tindak kekerasan. Maka apapun yang menjadi sasaran amarah, tempat ibadah, serta rumah penduduk dibom, dibakar, dan dihancurkan, sehingga para korban pun berjatuhan.

Akibatnya, praktek intoleransi banyak sekali ditemukan di bumi Indonesia ini. Padahal, keberagaman sudah mendarah daging dan menjadi watak bangsa Indonesia. Bahkan, berdirinya bangsa ini juga atas dasar keberagaman yang ada di dalamnya. ${ }^{3}$ Lebih jauh, tentu saja hal ini akan menjalar kepada lahirnya konflik-

\footnotetext{
${ }^{1}$ Abd. Moqsith Ghazali, Argumen Pluralisme Agama Membangun Toleransi Berbasis Alquran (Depok: Katakita, 2009), Xvii.

${ }^{2}$ Lihat www.eramuslim.com, "Fatwa MUI Tentang Haramnya Pluralisme, Liberalisme, dan Sekulerisme Agama", diakses tanggal 14 Maret 2018.

${ }^{3}$ Abdul Musi Naharong, "Teologi Kekerasan: Pandangan Jihad Abdul Salam Faraj dan Imam Samudra”, Falsafah dan Agama 1, 1 ( 2007), 335.
} 
konflik yang mengatasnamakan agama. Seperti kasus yang pernah terjadi di daerah Poso dan Ambon, di mana pelaku konflik banyak mendatangkan pihak dari luar daerah, baik dari Kristen, maupun dari Muslim itu sendiri. ${ }^{4}$ Kasus ini merupakan salah satu bukti dari ketidakbijaksanaan masing-masing penganut agama dalam menyikapi keberagaman tersebut, baik dari pihak muslim, maupun non-muslim.

Maka dari itu hemat penulis, timbulnya kasus intoleransi dan diskriminasi tersebut bermula dari ketidakbijaksanaan mereka dalam menyikapi pluralitas tersebut. Mereka hanya terbiasa berbuat baik kepada orang-orang yang sekeyakinan dengan mereka saja. Dan berlaku sebaliknya kepada orang-orang yang berbeda keyakinan. Jangankan untuk bersikap baik kepada seseorang yang berbeda keyakinan, memberikan kepedulian saja begitu enggan. Tidak heran jika sampai saat ini keadilan masih sulit untuk ditegakkan. Padahal di sisi lain, perlakuan seseorang kepada lainnya sangat mempengaruhi hubungan sosial di suatu lingkungan masyarakat.

Alquran sendiri telah memberikan gambaran bahwa setiap individu berhak untuk mendapatkan perlakuan baik dari individu lainnya. Terlepas dari perbedaan latar belakang dari masing-masing individu tersebut. Artinya, setiap orang diminta untuk selalu berbuat baik kepada siapapun tanpa melihat perbedaan. Dengan demikian, fenomena pluralitas tidak lagi dikatakan sebagai momok yang menyeramkan. Apalagi dianggap sesuatu yang dapat menyesatkan. Justru keberagaman inilah yang akan menghantarkan manusia menuju kerukunan dan perdamaian. Dengan catatan, setiap individu harus bijaksana dalam menyikapinya.

Lebih lanjut, Tulisan ini akan membahas mengenai spirit pluralitas yang tertuang dalam QS. Al-Bāqarah ayat 148. Penulis mencoba menyajikan bagaimana penafsiran ulama Indonesia, dalam hal ini ialah Quraish Shihab dengan tafsir Al-Misbahnya, lalu mencoba untuk merelasikannya dengan konteks Indonesia saat ini yang tengah marak dilanda problem konflik antar umat beragama. Karena memang, QS. Al-Bāqarah ayat 148 ini turun dalam konteks perpindahan kiblat. Dengan menggunakan metode deskriptif-analitis, diharapkan

${ }^{4}$ Lufaefi, "Menusantarakan Alquran: Mengembalikan Kegemilangan Budaya Kerukunan Antar Umat Beragama", Al-Ashlah 1, 2 (2017), 3. 
tulisan ini mampu menyingkap bagaimana tujuan dari ayat tersebut, dan sikap yang harus ditumbuhkan dalam menjawab tantangan pluralitas tersebut. Sehingga kita dapat membumikan toleransi di bumi pertiwi ini, dan mampu merasakan indahnya perdamaian di bawah payung keberagaman dan perbedaan.

\section{Pluralitas dan Pluralisme Agama; Tinjauan Umum Berbasis Alquran}

Definisi pluralitas berawal kata plural yang bermakna banyak, atau lebih dari satu. Begitu juga dengan istilah pluralisme. Dalam Kamus Besar Bahasa Indonesia (KBBI) kedua istilah ini diartikan sebagai kemajemukan atau keadaan masyarakat yang majemuk. ${ }^{5}$ Intinya, keduanya sama-sama menunjukkan bentuk jamak atau tidak satu. Sehingga pluralitas dan pluralisme agama dapat diartikan sebagai kemajemukan atau keberagaman agama. ${ }^{6}$

Sementara secara terminologi, telah banyak pakar yang memberikan pandangannya terkait dua istilah ini. Di antaranya ada yang membedakan antara pluralitas dan pluralisme, dan ada juga yang menyamakan antara keduanya. Pluralisme sering diartikan sebagai teori atau paham yang menyatakan bahwa realitas terdiri dari banyak substansi. ${ }^{7}$ Sehingga bisa dimengerti bahwa pluralisme merupakan suatu realitas yang meniscayakan adanya perbedaan dan keragaman, namun hal yang harus diperhatikan ialah tidak bisa memahami pluralisme dengan pengertian yang mutlak, terlebih lagi jika dilihat dalam kehidupan umat beragama. $^{8}$

Masih berkenaan dengan pluralitas dan pluralisme, Ulil Abshar Abdallah, seorang cendekiawan muslim Indonesia juga memberikan gagasannya, sekaligus memberikan klarifikasi terkait fatwa MUI beberapa tahun lalu yang mengharamkan konsep Pluralisme yang dianggap bertentangan dengan Islam. Menurutnya, ada kekeliruan dalam memahami konsep tersebut. Dalam fatwa tersebut dibuat suatu pembedaan antara dua konsep pluralitas dan pluralisme. Pluralisme dinyatakan haram karena ia sebagai isme (paham/aliran), sementara

\section{${ }^{5} \mathrm{KBBI}$ Online.}

${ }^{6}$ Purwadarminta, Kamus Umum Bahasa Indonesia (Jakarta: Balai Pustaka, 1983). 602 .

${ }^{7}$ M. Dahlan Al-Barry dan Partanto, Kamus Populer Ilmiah (Surabaya: Arkola Offset, 2001),

\footnotetext{
${ }^{8}$ Nuny Firdausia, "Alquran Menjawab Tantangan Pluralisme Terhadap Kerukunan Umat Beragama", Ulul Albab 14, 1 (2014), 46.
} 
pluralitas diperbolehkan karena ia bukan isme, tetapi hanya sekedar menunjukkan saja bahwa ada keragaman dalam masyarakat. Pluralisme dianggap sebagai paham yang mengajak umat islam untuk menyamaratakan seluruh agama. ${ }^{9}$

Merujuk kepada pluralism project, sebuah lembaga yang didirikan oleh Prof. Diana L. Eck dari Harvard University, Ulil Abshar berkesimpulan bahwa istilah pluralisme bukanlah ide yang memaksakan persamaan, melainkan lebih mengarah kepada tindakan aktif kita untuk bergumul dengan keragaman yang ada dalam masyarakat. Sehingga beliau mengibaratkan pluralitas dan pluralisme ini seperti dua sisi dari koin yang sama, yang tidak bisa dipisahkan. ${ }^{10}$ Jika hanya mengakui pluralitas, dalam artian hanya mengakui keragaman saja, itu bukanlah hal yang istimewa. Seharusnya setelah mengakui adanya keragaman tersebut, maka dibarengi dengan tindakan aktif bergumul dengan keragaman tersebut. ${ }^{11}$

Dengan demikian, secara sederhana pluralitas dapat diartikan dengan sikap mengakui eksistensi agama lain. Sebagamaina hal ini juga diperintahkan oleh Allah SWT (lihat QS. Al-Kāfirūn: 1-6). Sementara Pluralisme, tidak hanya diartikan sebagai sikap yang bisa menerima dan mengakui adanya agama lain, tapi juga diartikan sebagai suatu kesediaan untuk bisa berlaku adil kepada umat agama lain. Hal itu didasarkan pada prinsip mendahulukan nilai-nilai kemanusiaan. Sebagaimana juga sejalan dengan firman Allah "Allah tidak melarang kamu berbuat baik dan berlaku adil terhadap orang-orang yang tidak memerangimu dalam urusan agama dan tidak mengusirmu dari kampung halamanmu. Sesungguhnya Allah mencintai orang-orang yang berlaku adil." (QS. AlMumtahanah: 8)

Di samping itu, Alquran sebenarnya banyak sekali memberikan isyaratisyarat tentang pluralisme keagamaan tersebut. Di antaranya dalam QS. AlḤujurāt: 13;

${ }^{9}$ Ulil Abshar Abdalla, "Pluralisme dan Pluralitas: Dua Sisi Dari Koin Yang Sama", dalam www.Islamlib.com 29 September 2018.

${ }^{10}$ Liza Wahyuninto dan Abd. Qadir Muslim, Memburu Akar Pluralisme Agama: Mencari Isyarat-Isyarat Pluralisme Agama dalam Alquran dan Pelbagai Perspektif (Malang: UIN Maliki Press, 2010), 58.

${ }^{11}$ Ulil Abshar Abdalla, "Pluralisme dan Pluralitas: Dua Sisi Dari Koin Yang Sama", dalam www.Islamlib.com 29 September 2018. 


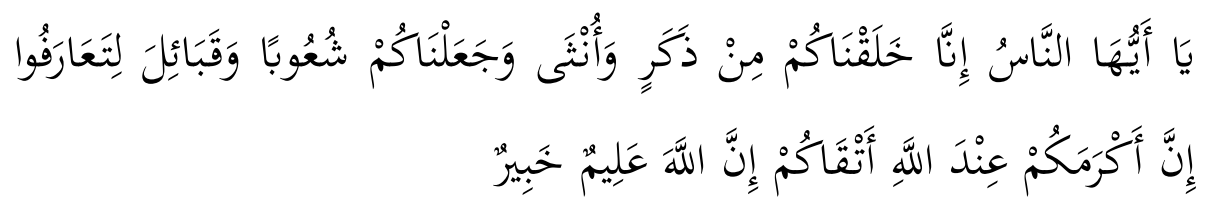

Hai manusia, sesungguhnya kami menciptakan kamu dari seorang lelaki dan perempuan, dan menjadikan kamu berbangsa-bangsa dan bersuku-suku supaya kamu saling kenal mengenal. Sesungguhnya orang yang paling mulia di antara kamu di sisi Allah ialah orang yang paling bertakwa. Sesungguhnya Allah maha mengetahui lagi maha mengenal.

Ayat di atas menerangkan tentang Allah ta'āla yang telah menciptakan makhlukn-Nya dengan berbeda-beda untuk menjalin hubugan yang baik di dunia. Kata ta' $\bar{a} r a f u \bar{u}$ pada ayat ini bukan hanya bermakna interaksi saling mengenal saja, melainkan interaksi positif. Karena itu setiap hal yang baik dinamakan $m a{ }^{\prime} r u \bar{f} .^{12}$ Dengan demikian, dijadikannya manusia beraneka ragam adalah dengan harapan bahwa antara satu dengan yang lainnya dapat berinteraksi secara baik dan positif. Artinya, interaksi positif juga sangat diharapkan menjadi sarana untuk mencapai perdamaian di dunia ini. ${ }^{13}$

Selanjutnya juga dipertegas dengan QS. al-Māi'dah: 48, Allah menegaskan bahwa sebenarnya Dia mampu menciptakan manusia dalam satu umat atau satu bangsa saja. Tetapi Allah menciptakan manusia beraneka ragam itu untuk menguji apakah mereka akan tetap konsisten dengan tuntunan-Nya, atau malah menyimpang. Hal ini juga senada dengan QS. Hūd: 118, di mana jika Allah menghendaki, amat gampang sekali untuk menciptakan manusia dalam satu bentuk, tetapi Dia tidak menghendaki hal tersebut. Ini menujukkan kepada realita bahwa pada hakikatnya manusia itu berbeda. Dan Allah menghendaki interaksi positif dalam keragaman tersebut, dan saling menghormati. ${ }^{14}$

\footnotetext{
${ }^{12}$ Liza Wahyuninto dan Abd. Qadir Muslim, Memburu Akar Pluralisme Agama: Mencari Isyarat-Isyarat Pluralisme Agama dalam Alquran dan Pelbagai Perspektif, 70.

${ }^{13}$ M. Arfan Muammar, dkk, Studi Islam: Perspektif Insider dan Outsider (Yogyakarta: Irscisod, 2012), 476.

${ }^{14}$ Liza Wahyuninto dan Abd. Qadir Muslim, Memburu Akar Pluralisme Agama: Mencari Isyarat-Isyarat Pluralisme Agama dalam Alquran dan Pelbagai Perspektif, 72.
} 


\section{Pluralitas Agama Dalam QS. Al-Bāqarah: 148}

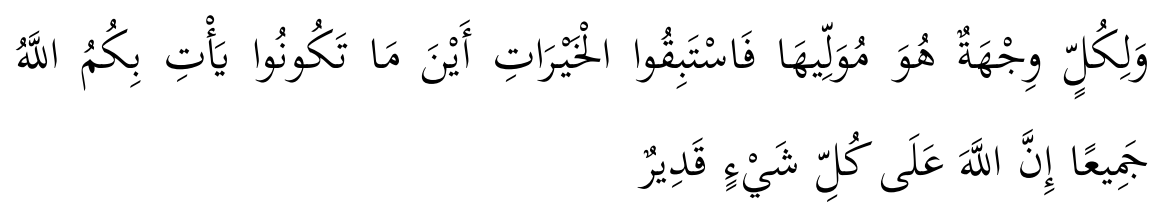

"Dan setiap umat mempunyai kiblat yang dia menghadap kepadanya.

Maka berlomba-lombalah kamu dalam kebaikan. Di mana saja kamu berada, pasti Allah akan mengumpulkan kamusemuanya. Sungguh, Allah maha kuasa atas segala sesuatu.” (QS. Al-Bāqarah: 148)

Dalam tafsir Al-Mishbah, Quraish Shihab menjelaskan bahwa ayat ini masih berbicara dalam konteks perpindahan kiblat. ${ }^{15}$ Beliau juga menjelaskan bahwa minimalnya ayat ini bisa dipahami dalam tiga penafsiran:

Pertama, bagi setiap umat ada kiblatnya sendiri-sendiri yang ia menghadap kepadanya. Begitu pun dengan kaum muslimin yang juga memiliki kiblat sendiri. Namun, kiblat kaum muslimin telah ditetapkan langsung oleh Allah SWT. Maka dari itu, kaum muslimin satu dengan yang lainnya diperintahkan untuk saling berlomba-lomba dalam kebaikan. ${ }^{16}$ Dengan kata lain, ayat ini dipahami bahwa khitobnya tertuju hanya kepada orang-orang muslim saja. Sehingga perintah berlomba-lomba dalam kebaikan pada ayat tersebut, juga hanya ditujukan kepada orang-orang muslim, agar di antara mereka (orang-orang muslim) dapat bersaing dalam kebaikan.

Kedua, bagi setiap umat ada kiblatnya sendiri yang ia menghadap kepadanya. Setiap umat bebas menghadap arah yang sesuai dengan kecenderungan atau keyakinan masing-masing. Dengan catatan, mereka tetap bertujuan untuk mencapai ridha Allah, sehingga mereka senantiasa melakukan kebaikan. Maka dari itu, kaum muslimin diperintahkan untuk berlomba dengan mereka dalam berbuat kebaikan. ${ }^{17}$ Lebih luas dari penafsiran sebelumnya, khitāb ayat ini tidak hanya diperlihatkan kepada orang-orang yang beriman saja. Bahkan ditujukan kepada seluruh umat manusia, muslim maupun nonmuslim. Sehingga perintah untuk berlomba dalam berbuat baik pada ayat ini juga ditujukan kepada

\footnotetext{
${ }^{15}$ M. Quraish Shihab, Tafsir Al-Mishbah, Pesan, Kesan, dan Keserasian Alquran (Jakarta: Lentera Hati, 2005), 344.

${ }^{16}$ M. Quraish Shihab, Tafsir Al-Mishbah, Pesan, Kesan, dan Keserasian Alquran, 344.

${ }^{17}$ M. Quraish Shihab, Tafsir Al-Mishbah, Pesan, Kesan, dan Keserasian Alquran, 355.
} 
semua. Umat muslim juga bersaing dengan umat non-muslim dalam melakukan kebaikan. Begitupun sebaliknya.

Ketiga, ayat ini juga dapat mengandung makna bahwa Allah benar-benar pernah memberikan perintah kepada bani Israil melalui lisan Nabi-nabi yang diutus oleh-Nya untuk menghadap ke arah tertentu, tapi perintah untuk menghadap ke Ka'bah kali ini ialah perintah yang tidak hanya ditujukan kepada bani Israil, tapi ditujukan kepada seluruh umat manusia. Namun, jika mereka tidak mau mengikuti tuntunan Allah untuk menghadap Ka'bah, maka biarkan saja mereka, dan tetaplah berlomba dengan mereka dalam berbuat kebaikan. Sehingga apapun dan di manapun posisi kalian, atau ke arah manapun manusia menghadap, pada akhirnya pasti Allah kumpulkan juga manusia yang beraneka ragam arahnya itu, untuk diberi keputusan yang hak. ${ }^{18}$

\section{Kandungan QS. Al-Bāqarah: 148; Meneguhkan Spirit Pluralitas}

Berdasarkan penafsirannya, QS. Al-Bāqarah ayat 148 ini memang turun dalam konteks perpindahan kiblat. Namun, tentu saja bukan hanya sebatas hal itu yang dapat dipahami. Melainkan banyak sekali point-point penting yang terkandung dalam ayat ini jika diteliti dan dipahami lebih dalam lagi. Terlebih dalam menggali pesan yang dapat diamalkan dalam kehidupan sehari-hari. Dalam hal ini ialah bagaimana menyikapi adanya tantangan pluralitas yang ada di masyarakat.

Bagian ayat ini mengulas prinsip moral bahwa pada hakikatnya tujuan semua agama selalu sama, yaitu beriman dan beramal saleh. ${ }^{19}$ Dari sini dapat dipahami bahwa spirit pluralitas yang ditekankan dalam ayat ini ialah semangat untuk berbuat kebaikan kepada siapapun dan di manapun. Tidak memandang perbedaan latar belakang, apalagi memandang perbedaan keyakinan. Perbedaanperbedaan yang ada tersebut, seharusnya menjauhkan manusia dari perselisihan,

\footnotetext{
${ }^{18}$ M. Quraish Shihab, Tafsir Al-Mishbah, Pesan, Kesan, dan Keserasian Alquran, 356.

${ }^{19}$ Ziauddin Sardar, Ngaji Qur'an di Zaman Edan; Sebuah Tafsir Untuk Menjawab Persoalan Mutakhir (Jakarta: Serambi Ilmu Semesta, 2014), 200.
} 
dan sebaliknya justru mendorong mereka untuk senantiasa bekerja sama dalam urusan dunia. $^{20}$

Spirit pluralitas dalam ayat ini juga senada dengan QS. al-Mā'idah: 48, “... untuk setiap umat di antara kamu, kami berikan aturan dan jalan yang terang. Kalau Allah menghendaki, niscaya kamu dijadikan-Nya satu umat saja, tetapi Allah hendak menguji kamu terhadap karunia yang telah diberikan-Nya kepadamu, maka berlomba-lombalah dalam berbuat kebajikan..." Dalam ayat ini, Allah semakin mengukuhkan kebebesan beragama tanpa adanya diskriminasi sedikitpun. Dengan memberi kesempatan kepada pemeluk Yahudi untuk menjalankan ajaran Taurat, dan kepada kaum Nasrani juga dipersilahkan untuk tetap menjalankan ajaran Injil (QS. al-Mā’idah: 43 dan 47). Maka dari itu, kedua ayat ini dapat saling menguatkan satu sama lainnya. ${ }^{21}$

Lebih jauh, agaknya QS. al-Mā'idah: 48 di atas memiliki kesamaan misi dengan QS. al-Bāqarah: 148, yaitu keduanya sama-sama bertujuan untuk memantapkan ukhuwah sesama manusia. Tidak perlu memandang perbedaan, karena perbedaan tersebut selain merupakan kehendak Allah, juga merupakan pangkal dari kelestarian hidup, sekaligus nantinya dapat tercapai segala tujuan kehidupan makhluk di pentas bumi. Tugas kita hanya mencari titik singgung dan titik temu dari perbedaan tersebut. Maka jelas, titik temu dari keberagaman agama yaitu sama-sama mengajarkan untuk selalu berbuat baik kepada sesama. Sekalipun tidak ditemukan persamaan, setidaknya Alquran mengajarkan kita agar mengetahui masalah masing-masing tanpa perlu menyalahkan orang lain. ${ }^{22}$

Dari sini juga, dapat dipahami bahwa dengan adanya perbedaan-perbedaan tersebut, Allah memerintahkan agar untuk saling berlomba-lomba mencapai ridha Allah Swt dan menuju jalan kebaikan. Maka, esensi agama-agama bukanlah hanya sekedar kesatuan saja, melainkan juga harus mengakui dan menghormati adanya perbedaan dengan agama yang lain. ${ }^{23}$

${ }^{20}$ M. Yusuf Wibisono, “Agama, Kekerasan dan Pluralisme Dalam Islam”, Kalam 9, 2 (2015), 200. Lihat juga Ali Masykur Musa, Membumikan Islam Nusantara; Respon Islam Terhadap Isu-Isu Aktual (Jakarta: Serambi Ilmu Semesta, 2014), 54.

${ }^{21}$ Irwan Masduqi, Berislam Secara Toleran; Teologi Kerukunan Umat Beragama (Bandung: Mizan Pustaka, 2011), 75.

${ }^{22}$ M. Quraish Shihab, Wawasan Alquran; Tafsir Maudhu'i Atas Pelbagai Persoalan Umat (Bandung: Mizan, 1996), 491-493.

${ }^{23}$ M. Yusuf Wibisono, “Agama, Kekerasan dan Pluralisme Dalam Islam”, 202. 
Dalam konteks berlomba-lomba dalam kebajikan yang dimaksud dalam ayat ini, dapat dikaitkan dengan QS. Al-Bāqarah: 62 "Orang-orang mukmin, orangorang Yahudi, orang-orang Nasrani dan orang-orang Shabi'in, siapa saja di antara mereka yang benar-benar beriman kepada Allah dan Hari Akhir, serta melakukan kebaikan (amal shaleh), maka tidak ada kekhawatiran kepada mereka, dan tidak pula mereka bersedih hati". Ayat ini jelas sekali mendukung pluralitas agama. Terkait ayat ini juga, M. Rasyid Riḍā' memberikan komentar bahwa ayat ini sangat jelas menegaskan bahwa kaum muslimin tidak boleh mengaveling surga seraya menganggap kaum Yahudi dan Nasrani sebagai ahli neraka, sebab kunci keselamatan bukanlah berupa status muslim yang disandang seseorang, melainkan hanya dapat diperoleh dengan iman dan amal shaleh. Artinya, semuanya berpotensi untuk memperoleh keselamatan, asalkan mampu bersaing dalam berbuat kebaikan atau amal saleh. ${ }^{24}$

Kembali kepada QS. al-Bāqarah ayat 148, jika dipahami secara komprehensif ayat ini mengingatkan kita bahwa agama bukan hanya sekedar ibadah atau arah seseorang dalam shalat (kiblat) saja. Melainkan lebih banyak dan lebih luas dari itu. Memang setiap agama memiliki makna simbolik atau ritual masing-masing, tetapi itu bukanlah esensi agama. Ritual ibadah yang berbeda tidak boleh dijadikan alasan untuk berpaling dari tujuan sejati agama. Apalagi dijadikan alasan untuk memecah belah apa yang telah disatukan. Maka dari itu, di akhir ayat ini ditekankan bahwa semua umat dalam keragaman tersebut pada akhirnya akan dihubungkan dan disambungkan oleh kedudukan mereka sebagai makhluk ciptaan Allah dan akan kembali dikumpulkan di hadapan-Nya untuk diadili pada hari kiamat. Dan terakhir, bukanlah perbedaan arah dalam ibadah (keyakinan) yang akan dimintakan pertanggungjawaban, melainkan baik atau buruknya amal perbuatan mereka di dunia. ${ }^{25}$

Memperkuat hal tersebut, Budi Munawar $\operatorname{Rahman}^{26}$ juga memiliki pandangan bahwa setiap umat mempunyai wijhah yang ditandai dengan konsep

\footnotetext{
${ }^{24}$ Irwan Masduqi, Berislam Secara Toleran; Teologi Kerukunan Umat Beragama, 77.

${ }^{25}$ Ziauddin Sardar, Ngaji Qur'an di Zaman Edan; Sebuah Tafsir Untuk Menjawab Persoalan Mutakhir, 201-203.

${ }^{26}$ Budi Munawar Rahman, dalam "kata pengantar" bukunya M. Fathi Osman, Islam, Pluralisme, dan Toleransi Keagamaan: Pandangan Alquran, Kemanusiaan dan Sejarah Peradaban (Jakarta: Democracy Project Yayasan Demokrasi, 2012).
} 
tempat suci, waktu suci, hari suci, dan lain-lain. Alquran menjelaskan agar manusia tidak memperdebatkan adanya wijhah untuk golongan tertentu, sebab hal yang terpenting adalah manusia berikhtiyar untuk meraih banyak kebaikan (fastabiq al-khairāt). Di mana saja manusia berada, Allah akan menjadika semuanya berkumpul dan bersatu. Hal itu mengindikasikan adanya argumen tentang "kesatuan" dan "keberbedaan" agama-agama secara sekaligus. Kedua makna tersebut sanga penting jika digunakan sebagai solusi memecahkan masalah hubungan antar agama. Maka, tidak harus membeda-bedakan agama yang satu dengan agama yang lain. ${ }^{27}$ Hanya saja, kewajiban terpenting yang harus diwujudkan ialah kesamaan esensi dan tujuan dari agama-agama yang ada, yaitu mengajarkan tentang kasih sayang serta berusaha menciptakan perdamaian di antara sesama manusia.

\section{Membumikan Toleransi di Indonesia Dengan Spirit Pluralitas Perspektif}

\section{Alquran}

Indonesia adalah Bangsa yang majemuk, kemajemukan tersebut meniscayakan adanya keragaman agama dan budaya. Dikatakan bahwa agamaagama yang ada di Indonesia hampir mewakili semua agama besar yang ada di dunia, selain agama-agama asli yang jumlahnya banyak sekali. ${ }^{28}$ Pluralitas memang bukan merupakan fenomena baru bagi bangsa Indonesia, sehingga tak heran jika keberagaman tersebut sangat mewarnai tradisi politik dan praktek keagamaan orang muslim di Indonesia. ${ }^{29}$

Di satu sisi hal itu menjadi nilai plus tersendiri bagi kekhasan identitas bangsa Indonesia. Namun di sisi lain, pluralitas tersebut menyimpan potensi konflik yang begitu besar. Artinya, jika hal itu tidak bisa disikapi secara bijaksana, maka sangat mungkin sekali akan menjadi pemicu terjadinya diskriminasi dan intoleransi di negeri ini. Padahal sebaliknya, keragaman tersebut harusnya menjadi sarana untuk saling mengenal. Dengan saling mengenal perbedaan, manusia bisa belajar membangun peradaban. Dengan saling tahu

\footnotetext{
${ }^{27}$ Lihat juga M. Yusuf Wibisono, “Agama, Kekerasan dan Pluralisme Dalam Islam”.

${ }^{28}$ Azyumardi Azra, dkk., Nilai-Nilai Pluralisme Dalam Islam; Bingkai Gagasan Yang Berserak (Bandung: Penerbit Nusantara, 2005), 184.

${ }^{29}$ Nuny Firdausia, "Alquran Menjawab Tantangan Pluralisme Terhadap Kerukunan Umat Beragama”, Ulul Albab, 14, 1 (2014), 49.
} 
perbedaan di antara manusia, maka itu akan membuatnya lebih toleran. Justru kesalahpahaman sering terjadi karena belum adanya saling mengenal keragaman di antara manusia. ${ }^{30}$

Pluralitas merupakan proses yang terus-menerus yang berasal dari sikap toleransi moral. Maka dari itu, antara pluralitas dan toleransi tidak dapat dipisahkan. Jika pluralitas tidak diindahkan dengan adanya toleransi, suatu negara tidak akan dapat mewujudkan perdamaian. Setiap orang diminta untuk menumbuhkan spirit pluralitas dengan saling menjaga satu sama lain merupakan kesetaraan dan meningkatkan rasa persaudaraan sesama manusia, baik secara individu maupun kelompok. Selain itu, semagat pluralitas ini harus diwujudkan dengan mengedepankan kerja sama untuk menciptakan nilai-nilai kemanusiaan, dan memberikan kesempatan yang sama kepada pihak lain terutama hak-hak sipilnya atas nama warga bangsa, maupun warga dunia. ${ }^{31}$

Agar dalam pluralitas tidak mengindikasikan adanya konflik antar umat beragama, maka diperlukan adanya nilai-nilai toleransi. Toleransi bisa menjadi dasar kebebasan bagi semua orang. Dengan begitu, setiap individu akan bisa menghormati dan menghargai orang lain. Jadi, Yusuf al-Qarḍāwī berpendapat bahwa mempunyai spirit bertoleransi yang tinggi, akan mengaplikasikan pada pergaulan yang baik, sikap yang lemah lembut, kasih sayang, lapang dada, dan akan selalu berbuat iḥsān kepada orang lain yang bebeda agama. Sikap yang seperti ini bisa tertuang jelas dalam Alquran. Misalnya, perintah untuk tetap berbuat baik kepada kedua orang tua sekalipun berbeda agama dengannya (QS. Luqmān: 15), perintah untuk tetap berbuat adil kepada non-Muslim yang tidak memerangi kaum muslimin karena agama (QS. Al-Mumtahanah: 8), dan lainlain. $^{32}$

Di samping itu, Nasaruddin Umar dalam bukunya memaparkan begitu jelas bagaimana makna toleransi dalam pandangan Islam. Beliau mengatakan bahwa toleransi hadir sebagai bukti adanya pengakuan Islam terhadap hak-hak asasi masing-masing individu manusia, seperti hak persamaan dan kebebasan, hak

\footnotetext{
${ }^{30}$ Nadirsyah Hosen, Tafsir Alquran di Medsos; Mengkaji Makna dan Rahasia Ayat Suci Pada Era Media Sosial (Yogyakarta: Penerbit Bunyan, 2017), 149.

${ }^{31}$ M. Yusuf Wibisono, “Agama, Kekerasan dan Pluralisme Dalam Islam”, 200.

${ }^{32}$ Sukron Ma'mun, "Pluralisme Agama dan Toleransi Dalam Islam Perspektif Yusuf alQarạ̄āwī”, Humaniora 4, 2 (2013), 1224-1226.
} 
hidup, hak memperoleh perlindungan dan pendidikan, hak keadilan, hak rasa aman, dan sebagainya. Toleransi juga dapat berarti lapang dada, sabar, tahan terhadap sesuatu dan dapat menerima. Toleransi dalam bahasa Arab, dikenal dengan istilah tasamuh yang mempunyai makna sikap membiarkan berbeda dan tidak memkasa, berlaku baik, lemah lembut, dan saling memaafkan. ${ }^{33}$

Lebih lanjut, beliau juga menegaskan bagaimana toleransi dipandang dalam perspektif kerukunan hidup antar umat manusia. Menurut beliau, agar mencapai kerukunan antar umat, maka toleransi tersebut mesti diaplikasikan dalam bentuk sikap saling tolong menolong, saling menghargai, saling menyayangi, percaya dan tidak saling curiga. Atau lebih kepada sikap saling menghargai hak-hak sebagai manusia, anggota masyarakat dalam suatu negara, yaitu Indonesia. Bagi masyarakat muslim, yang menjadi mayoritas di Indonesia harus mampu menerjemahkan ajaran Islam tersebut di tengah-tengah kehidupan yang plural dengan sikap penghargaan, kemaslahatan, keselamatan, dan kedamaian masyarakat, serta mencegah kemudharatan, kerusakan, bahkan kebencian. ${ }^{34}$

Dengan demikian, spirit pluralitas yang terkandung dalam QS. Al-Bāqarah: 148 juga termasuk salah satu upaya dalam membumikan toleransi di Indonesia. Yaitu semangat untuk selalu menebarkan kebaikan kepada siapapun tanpa memandang perbedaan agama dan latar belakang. Ketika seorang mampu terus menerus dalam berbuat kebaikan, maka ketika itu pula ia sedang menjalankan hakikat agama yang sebenarnya. Sehingga Gus Dur, bapak Pluralisme Indonesia pernah mengatakan "jika kamu selalu melakukan kebaikan, maka orang lain tidak akan lagi mempertanyakan apa agamamu?". Karena perilaku yang baik merupakan cerminan dari agama yang baik.

\section{Kesimpulan}

Pemahaman kontekstual terhadap QS. Al-Bāqarah ayat 148 di atas selain melegitimasi dan mendukung adanya fenomena pluralitas, ayat ini sekaligus menawarkan sikap yang bijak dalam menghadapi tantangan pluralitas tersebut. Sikap bijak inilah yang penulis sebut dengan spirit pluralitas. Yaitu

\footnotetext{
${ }^{33}$ Nasaruddin Umar, Deradikalisasi Pemahaman Alquran dan Hadis (Jakarta: Kompas Gramedia, 2014), 359.

${ }^{34}$ Nasaruddin Umar, Deradikalisasi Pemahaman Alquran dan Hadis, 400.
} 
menumbuhkan semangat dalam melakukan kebaikan, serta bersaing dengan umat lain dalam berbuat baik tanpa memandang adanya perbedaan. Termasuk di dalamnya semangat untuk membungkam diskriminasi dan intoleransi. Sehingga selalu berusaha menumbuhkan toleransi di tengah-tengah kemajemukan tersebut.

Lebih lagi di Indonesia yang telah diakui memiliki berbagai realitas keberagaman. Maka spirit pluralitas ini sangat penting untuk diaktualisasikan. Masyarakat Indonesia tidak diminta untuk menghindari atau melepaskan diri dari fenomena pluralitas ini, karena memang tidak akan pernah dapat dihindari. Maka dari itu, masyarakat Indonesia diharapkan mampu mengaplikasikan spirit pluralitas yang terkandung dalam QS. Al-Bāqarah ayat 148 tersebut. Dengan selalu berusaha melakukan kebaikan kepada siapapun, maka tentu saja akan mengurangi adanya konflik antar umat agama. Sehingga masyarakat Indonesia akan merasakan perdamaian dan keharmonisan.

\section{Daftar Pustaka}

Abdalla, Ulil Abshar, "Pluralisme dan Pluralitas: Dua Sisi Dari Koin Yang Sama”, dalam www.Islamlib.com/gagasan/pluralisme/pluralisme-danpluralitas-dua-sisi-dari-koin-yang-sama/ 29 September 2018.

Azra, Azyumardi, dkk. Nilai-Nilai Pluralisme Dalam Islam; Bingkai Gagasan Yang Berserak. Bandung: Penerbit Nusantara, 2005.

Al-Barry, M. Dahlan dan Partanto. Kamus Populer Ilmiah. Surabaya: Arkola Offset, 2001.

Firdausia, Nuny. “Alquran Menjawab Tantangan Pluralisme Terhadap Kerukunan Umat Beragama”. Ulul Albab 14, 1 (2014).

Ghazali, Abd. Moqsith. Argumen Pluralisme Agama Membangun Toleransi Berbasis Alquran. Depok: Katakita, 2009.

Hosen, Nadirsyah. Tafsir Alquran di Medsos; Mengkaji Makna dan Rahasia Ayat Suci Pada Era Media Sosial. Yogyakarta: Penerbit Bunyan, 2017.

Lufaefi, "Menusantarakan Alquran: Mengembalikan Kegemilangan Budaya Kerukunan Antar Umat Beragama”, jurnal Al-Ashlah 1, 2 (2017).

Masduqi, Irwan. Berislam Secara Toleran; Teologi Kerukunan Umat Beragama. Bandung: Mizan Pustaka, 2011. 
Ma'mun, Sukron. "Pluralisme Agama dan Toleransi Dalam Islam Perspektif Yusuf Al-Qaradhawi”. Humaniora 4, 2 (2013).

Muammar, M. Arfan. dkk. Studi Islam: Perspektif Insider dan Outsider. Yogyakarta: Irscisod, 2012.

Musa, Ali Masykur. Membumikan Islam Nusantara; Respon Islam Terhadap IsuIsu Aktual. Jakarta: Serambi Ilmu Semesta, 2014.

Naharong, Abdul Musi. "Teologi Kekerasan: Pandangan Jihad Abdul Salam Faraj dan Imam Samudra”, jurnal Falsafah dan Agama 1, 1 (2007).

Purwadarminta. Kamus Umum Bahasa Indonesia. Jakarta: Balai Pustaka, 1983.

Rahman, Budi Munawar. dalam "kata pengantar" bukunya M. Fathi Osman. Islam, Pluralisme, dan Toleransi Keagamaan: Pandangan Alquran, Kemanusiaan dan Sejarah Peradaban. Jakarta: Democracy Project Yayasan Demokrasi, 2012.

Sardar, Ziauddin. Ngaji Qur'an di Zaman Edan; Sebuah Tafsir Untuk Menjawab Persoalan Mutakhir. Jakarta: Serambi Ilmu Semesta, 2014.

Shihab, M. Quraish. Tafsir Al-Mishbah, Pesan, Kesan, dan Keserasian Alquran. Jakarta: Lentera Hati, 2005.

Umar, Nasaruddin. Deradikalisasi Pemahaman Alquran dan Hadis. Jakarta: Kompas Gramedia, 2014.

Wahyuninto, Liza dan Abd. Qadir Muslim. Memburu Akar Pluralisme Agama: Mencari Isyarat-Isyarat Pluralisme Agama dalam Alquran dan Pelbagai Perspektif. Malang: UIN Maliki Press, 2010.

Wibisono, M. Yusuf. “Agama, Kekerasan dan Pluralisme Dalam Islam”, Kalam 9, $2(2015)$.

Sumber Lain:

KBBI Online

www.eramuslim.com. "Fatwa MUI Tentang Haramnya Pluralisme, Liberalisme, dan Sekulerisme Agama”, diakses tanggal 14 Maret 2018. 